Ascosenda Ika Rizqi, Bunyamin Maftuh, Elly Malihah

Vol 5 No 1

ISSN : 2541-6995

E ISSN : 2580-5517

\title{
Aktualisasi Nilai-Nilai Kepalangmerahan Dalam Kasus Demonstrasi Hasil Pemilu di Jakarta
}

\author{
Ascosenda Ika Rizqi ${ }^{1)}$, Bunyamin Maftuh $^{2)}$, Elly Malihah ${ }^{3)}$ \\ Senda.air@gmail.com ${ }^{1)}$, bmaftuh@yahoo.co.id ${ }^{2)}$, ellyms@upi.edu $^{3)}$ \\ Universitas Merdeka Pasuruan ${ }^{1)}$ \\ Universitas Pendidikan Indonesia ${ }^{2,3)}$
}

\begin{abstract}
Abstrak
Demokrasi menempati posisi vital dalam kaitannya pembagian kekuasaan dalam suatu negara. Pendidikan demokrasi tidak saja dalam kajian konsep verbalistik, melainkan telah membumi dalam interaksi dan pergaulan sosial baik dikelas maupun diluar kelas. Salah satu unsur pengamanan demonstrasi sesuai dengan protap negara adalah Palang Merah Indonesia (PMI). Palang Merah Indonesia merupakan organisasi yang bergerak di bidang sosial kemasyarakatan dan berbadan hukum. PMI melaksanakan tugasnya dengan berpedoman kepada prinsip dasar yaitu Gerakan Internasional Palang Merah dan Bulan Sabit merah serta berpedoman kepada Code of Conduct dan Saver Access dalam setiap melaksanakan tugasnya di lapangan serta dilindungi oleh payung hukum yang berlaku.
\end{abstract}

Kata Kunci: Demokrasi, PMI, Prinsip Dasar

\begin{abstract}
Democracy is at a critical position in relation to the sharing of power in a country. The education of democracy is not only in the study of verbalism but also in the social interactions and in both classes and outside classes. One of many elements of demonstration security in accordance with the state regular procedure is the Indonesian Red Cross (PMI). The Indonesian Red Cross is a socially organized, law-abiding organization. PMI conducts its duties guided to the fundamental principles of the international movement of the Red Cross and red crescent and guides to the code of conduct and saver access in each to conduct its duties in the field and protected by a prevailing legal umbrella.
\end{abstract}

Keywords: democracy, Indonesian Red Cross, Fundamental principles 
Ascosenda Ika Rizqi, Bunyamin Maftuh, Elly Malihah

Vol 5 No 1

ISSN : 2541-6995

E ISSN : 2580-5517

\section{Pendahuluan}

Menurut Sulesana (2011:15) Demokrasi menempati posisi vital dalam kaitannya pembagian kekuasaan dalam suatu negara (umumnya berdasarkan konsep dan prinsip trias politica) dengan kekuasaan negara yang diperoleh dari rakyat juga harus digunakan untuk kesejahteraan dan kemakmuran rakyat. Prinsip semacam trias politica ini menjadi sangat penting untuk diperhitungkan ketika fakta-fakta sejarah mencatat kekuasaan pemerintah (eksekutif) yang begitu besar ternyata tidak mampu untuk membentuk masyarakat yang adil dan beradab, bahkan kekuasaan absolut pemerintah seringkali menimbulkan pelanggaran terhadap hak-hak asasi manusia. Salah satu bentuk dari demokrasi baik yang ada di negara lain maupun Indonesia salah satunya adalah menyampaikan pendapat dengan cara demonstrasi.

Tujuh norma-norma dan pandangan hidup demokratis yang dikemukakan oleh Nurcholis Madjid (Cak Nun) dalam dalam Tri (2019:5), sebagai berikut:

a. Pentingnya kesadaran akan pluralisme. Hal ini tidak sekedar pengakuan (pasif) akan kenyataan masyarakat yang majemuk. Lebih dari itu, kesadaran akan kemajemukan menghendaki tanggapan yang positif terhadap kemajemukan itu sendiri secara aktif. Kesadaran akan pluralitas sangat penting dimiliki bagi rakyat Indonesia sebagai bangsa yang sangat beragam dari sisi etnis, bahasa, budaya, agama dan potensi alamnya.

b. Musyawarah Internaliasasi makna dan semangat musyawarah mengehendaki atau meharuskan keinsyafan dan kedewasaan untuk dengan tulus menerima kemungkinan terjadinya "partial finctioning of ideals", yaitu pandangan dasar belum tentu, dan tidak harus, seluruh keinginan sepenuhnya.

c. Pertimbangan moral Pandangan hidup demokratis mewajibkan adanya keyakinan bahwa cara haruslah sejalan dengan tujuan. Bahkan sesungguhnya klaim atas suatu tujuan yang baik harus diabsahkan oleh kebaikan cara yang ditempuh untuk meraihnya. Demokrasi tidak terbayang terwujud tanpa ahklak yang tinggi. Dengan demikian pertimbangan moral (keseluruhan akhlak) menjadi acuan dalam berbuta dan mencapai tujuan.

d. Permufakatan yang jujur dan sehat Suasana masyarakat demokratis dituntut untuk menguasai dan menjalankan seni permusyawaratan yang jujur dan sehat itu guna mencapai permufaakatan yang juga jujur dan sehat. Permufakatan yang dicapi melalui "engineering", manipulasi atau merupakan permufakatan yang curang, cacat atau sakit, malah dapat disebut sebagai penghianatan pada nilai dan semangat musyawarah. Musyawarah yang benar dan baik hanya akan berlangsung jika masing- masing pribadi atau kelompok yang bersangkutan memiliki kesediaan psikologis untuk melihat kemungkinan orang lain benar dan diri sendiri salah, dan bahwa setiap orang pada dasarnya baik, berkecenderungan baik, dan beriktikad baik.

e. Pemenuhan segi-segi ekonomi Masalah pemenuhan segi-segi ekonomi yang dalam pemenuhannya tidak lepas dari perencanaan sosial-budaya. Warga dengan pemenuhan kebutuhan secara berencana, dan harus memiliki kepastian bahwa rencana-rencana itu benarbenar sejalan dengan tujuan dan praktik demokrasi. Dengan demikian rencana pemenuhan kebutuhan ekonomi harus mempertimbangkan aspek keharmosian dan keteraturan sosial. 
Ascosenda Ika Rizqi, Bunyamin Maftuh, Elly Malihah

Vol 5 No 1

ISSN : 2541-6995

E ISSN : 2580-5517

f. Kerjasama antar warga untuk mempercayai iktikad baik masing- masing. Kerjasama antar warga untuk mempercayai iktikad baik masing- masing, kemudian jalinan dukung- mendukung secara fungsional antara berbagai unsur kelembagaan kemasyarakatan yang ada, merupakan segi penunjang efisiensi untuk demokrasi. Pengakuan akan kebebasan nurani (freedom of conscience), persamaan percaya pada iktikad baik orang dan kelompok lain (trust attitude) mengharuskan adanya landasan pandangan kemanusiaan yang positif dan optimis.

g. Pandangan hidup demokratis harus dijadikan unsur yang menyatu dengan pendidikan demokrasi. Pandangan hidup demokrasi terlaksana dalam abad kesadaran universal sekarang ini, maka nilai- nilai dan pengertian - pengertiannya harus dijadikan unsur yang menyatu dengan sistem pendidikan kita. Perlu dipikirkan dengan sungguh-sungguh memikirkan untuk membiasakan anak didik dan masyarakat umumnya siap menghadapi perbedaan dan pendapat dan tradisi pemilihan terbuka untuk mentukan pemimpin atau kebijakan.

Pendidikan demokrasi tidak saja dalam kajian konsep verbalistik, melainkan telah membumi dalam interaksi dan pergaulan sosial baik dikelas maupun diluar kelas. Tumbuh dan berkembangnya demokrasi dalam suatu Negara memerlukan ideology yang terbuka, yaitu ideologi yang tidak dirumuskan "sekali dan untuk selamanya" (once and for all), tidak dengan ideology tertutup yaitu ideology yang konsepnya (presept) dirumuskan " sekali dan untuk selamanya" sehingga cenderung ketinggalan zaman (obsolete, seperti terbukti dengan ideology komunisme). Demonstrasi menurut Nasih dan Lilik (2009:49) merupakan metode panyajian pelajaran dengan memeragakan dan menunjukkan kepada siswa mengenai suatu proses, situasi atau benda tertentu, baik sebenarnya atau hanya sekedar tiruan. Terlepas dari metode penyajian tidak terlepas dari penjelasan guru, walau dalam sebuah metode demonstrasi siswa haya sekedar memperhatikan yang artinya belum dalam taraf memperagakan. Penjelasan lain mengenai demonstrasi ditulis oleh Huda (2013:233) metode demonstrasi merupakan metode yang menggunakan peragaan untuk memperjelas atau pengertian atau untuk memperlihatkan bagaimana melakukan sesuatu kepada peserta lain. Demonstrasi merupakan metode pembelajaran yang efektif, karena peserta didik dapat mengetahui secara langsung penerapan materi tersebut dalam kehidupan sehari-hari.

Semenjak kemerdekaan 17 agustus 1945, Undang Undang Dasar 1945 memberikan penggambaran bahwa Indonesia adalah negara demokrasi.Dalam mekanisme kepemimpinannya Presiden harus bertanggung jawab kepada MPR dimana MPR adalah sebuah badan yang dipilih dari Rakyat. Sehingga secara hirarki seharusnya rakyat adalah pemegang kepemimpinan negara melalui mekanisme perwakilan yang dipilih dalam pemilu. Indonesia sempat mengalami masa demokrasi singkat pada tahun 1956 ketika untuk pertama kalinya diselenggarakan pemilu bebas di indonesia, sampai kemudian Presiden Soekarno menyatakan demokrasi terpimpin sebagai pilihan sistem pemerintahan. Setelah mengalami masa Demokrasi Pancasila, sebuah demokrasi semu yang diciptakan untuk melanggengkan kekuasaan Soeharto, Indonesia kembali masuk kedalam alam demokrasi pada tahun 1998 ketika pemerintahan junta militer Soeharto tumbang. Pemilu demokratis kedua bagi Indonesia terselenggara pada tahun 2004 Bisa dikatakan bahwa Indonesia sangat berpotensi menjadi kiblat demokrasi di kawasan Asia, berkat keberhasilan mengembangkan dan melaksanakan sistem demokrasi. Menurut Ketua Asosiasi Konsultan Politik Asia Pasifik (APAPC), Pri Sulisto, keberhasilan Indonesia dalam bidang demokrasi bisa menjadi contoh bagi negara-negara di kawasan Asia yang hingga saat ini beberapa di antaranya masih diperintah dengan 'tangan besi'. Indonesia juga bisa menjadi contoh, bahwa pembangunan sistem 
Ascosenda Ika Rizqi, Bunyamin Maftuh, Elly Malihah

Vol 5 No 1

ISSN : 2541-6995

E ISSN : 2580-5517

demokrasi dapat berjalan seiring dengan upaya pembangunan ekonomi. Ia menilai, keberhasilan Indonesia dalam bidang demokrasi yang tidak banyak disadari itu, membuat pihak luar termasuk Asosiasi Internasional Konsultan Politik (IAPC), membuka mata bangsa Indonesia, bahwa keberhasilan tersebut merupakan sebuah prestasi yang luar biasa. Prestasi tersebut juga menjadikan Indonesia sangat berpotensi mengantar datangnya suatu era baru di Asia yang demokratis dan makmur.

Salah satu unsur pengamanan demontrasi sesuai dengan protap negara adalah: Kepolisian, TNI dan tim kesehatan, adapun salah satu dari unsur tim kesehatan adalah Palang Merah Indonesia. Palang Merah Indonesia merupakan organisasi yang bergerak di bidang kemanusiaan dan kesehatan, yang salah satu tugasnya adalah melaksanakan tim kesehatan (timkes) dalam kegiatan apapun termasuk salah satunya adalah demonstrasi. Anggota Palang Merah Indonesia juga telah dibekali untuk bersikap netral dalam menangani dan menjaga setiap kegiatan karena hal tersebut telah menjadi salah satu pedoman yang harus di terapkan dalam setiap anggota Palang Merah Indonesia.

\section{Pembahasan}

Demonstrasi merupakan hal yang umum terjadi di setiap negara bahkan di negara demokrasi sekalipun seperti Indonesia sudah menjadi sesuatu yang sering di dengar dan di lihat, bentuk demonstrasi bermacam-macam, mulai dari hanya sekedar menyampaikan pendapat atau yang disebut sebagai demontrasi damai seperti halnya yang dicontohkan oleh jamaah 212 di Jakarta beberapa tahun yang lalu atau demontrasi yang dilakukan oleh mahasiswa yang menuntut haknya dengan meminta audiensi dengan pihak terkait, namun bahkan tidak jarang demonstrasi akan menimbulkan hal-hal yang berdampak kepada kekerasan seperti contoh pada saat terjadinya demonstrasi terkait kebijakan pemerintah Indonesia dalam mengambil sikap di Jakarta beberapa waktu lalu.

Demonstrasi terkait kebijakan pemerintah Indonesia yang terjadi di akhir bulan Desember 2019 beberapa waktu lalu memang sempat membuat kondisi wilayah terdampak demonstrasi sangat padat manusia dari beberapa wilayah dari tanah air, mahasiswa bergabung guna menyuarakan isi hati mereka kepada pemerintah agar Indonesia menjadi sebuah negara yang lebih baik lagi dan sesuai dengan amanat Pancasila terutama sila keempat yaitu kerakyatan yang dipimpin oleh hikmat kebijaksanaan dalam permusyawaratan perwakilan. Demonstrasi yang semula berjalan damai serta peserta aksi demonstrasi yang sabar menanti sebuah kebijakan yang diambil oleh pemerintah agar masa depan negara Republik Indonesia tidak berada pada titik nadir akhirnya harus jatuh dengan cara yang sebenarnya tidak diinginkan oleh pihak manapun baik dari perwakilan mahasiswa seantero Indonesia yang hadir pada saat itu maupun dari pihak alat negara atau pihak keamaan yaitu TNI dan Polri, sehingga dampak yang terjadi selanjutnya tentunya adanya tindakan persuasif dari masing-masing pihak baik itu keamanan negara maupun dari pihak peserta aksi demonstrasi.

Palang Merah merupakan organisasi yang bergerak di bidang sosial kemasyarakatan yang mana gerakan ini sudah ada sejak tahun 1859 serta sudah berdiri di semua negara yang ada di dunia ini hingga organisasi Palang Merah masuk ke Indonesia dan di resmikan pada 17 September 1945 atau tepat sebulan setelah Indonesia merdeka, Organisasi Palang Merah yang berada di Indonesia 
Ascosenda Ika Rizqi, Bunyamin Maftuh, Elly Malihah

Vol 5 No 1

ISSN : 2541-6995

E ISSN : 2580-5517

atau yang dikenal dengan nama Palang Merah Indonesia (PMI) yang saat ini di ketuai oleh Jusuf Kalla mantan wakil presiden Republik Indonesia periode 2004-2009 merupakan organisasi yang mempunyai satuan tugas terstruktur dan sudah dikenal oleh masyarakat luas umumnya di Indonesia. Staff Palang Merah Indonesia (PMI) maupun sukarelawan Palang Merah Indonesia (PMI) sejak awal sudah dibekali oleh prinsip dasar Palang Merah dan Bulan Sabit Merah atau yang dikenal oleh Gerakan Internasional Palang Merah dan Bulan Sabit Merah guna menghadapi kegiatan sehari-hari baik saat bertugas maupun sedang tidak bertugas serta dibekali dengan materi Saver Access dan Code of Conduct saat bertugas di lapangan dan tentunya sukarelawan Palang Merah Indonesia (PMI) juga di lindungi oleh Undang-Undang nomer 1 tahun 2018 tentang kepalangmerahan serta Peraturan Pemerintah nomer 7 tahun 2019 tentang Kepalangmerahan, adapun tujuan dari materi dan perturan tersebut guna memberikan kenyamanan dan rasa aman dalam melaksanakan tugas dilapangan, baik saat menolong korban maupun kegiatan PMI yang lain baik pada saat damai maupun terjadi konflik bersenjata.

Palang Merah Indonesia adalah organisasi kemanusiaan yang berstatus badan hukum, diundangkan dengan Undang-Undang nomor 1 tahun 2018 tentang Kepalangmerahan guna menjalankan kegiatan Kepalangmerahan sesuai dengan Konvensi Jenewa Tahun 1949, dengan tujuan untuk mencegah dan meringankan penderitaan dan melindungi korban tawanan perang dan bencana, tanpa membedakan agama, bangsa, suku bangsa, warna kulit, jenis kelamin, golongan, dan Pandangan Politik. Adapun tugas yang dilakukan oleh Palang Merah Indonesia adalah:

(a) Memberikan bantuan kepada korban konflik bersenjata, kerusuhan dan lainnya;

(b) Memberikan pelayanan darah sesuai dengan ketentuan peraturan perundang-undangan;

(c) Melakukan pembinaan relawan;

(d) Melaksanakan pendidikan dan pelatihan yang berkaitan dengan Kepalangmerahan;

(e) Menyebarluaskan informasi yang berkaitan dengan kegiatan Kepalangmerahan;

(f) Membantu dalam penanganan musibah dan/atau bencana di dalam dan di luar negeri;

(g) Membantu pemberian pelayanan kesehatan dan sosial;

(h) Melaksanakan tugas kemanusiaan lainnya yang diberikan oleh pemerintah.

Selain tujuan diatas anggota Palang Merah Indonesia juga dibekali dengan prinsip dasar atau yang disebut sebagai gerakan internasional Palang Merah dan Bulan Sabit Merah yang mana prinsip dasar tersebut harus terus terpatri dan digunakan dalam kehidupan sehari-hari baik dalam keadaan damai maupun dalam keadaan darurat, inilah salah satu yang dijadikan tameng bagi anggota Palang Merah dimana pun mereka berada, inilah salah satu fungsi lambang Palang Merah, selain sebagai tanda pengenal juga sebagai tanda pelindung bagi setiap anggotanya. Adapun Gerakan internasional Palang Merah dan Bulan Sabit Merah adalah sebagai berikut:

1. Kemanusiaan, organisasi Palang Merah dan Bulan Sabit Merah bergerak di bidang kemanusiaan, misi organisasi adalah murni untuk menolong sesame

2. Kesamaan, organisasi menganggap derajat manusia adalah sama sehingga tidak perlu membeda-bedakan SARA dalam melakukan pertolongan

3. Kenetralan, organisasi bersifat netral tidak memihak manapun dan siapapun

4. Kemandirian, organisasi bersifat mandiri, tidak melibatkan organisasi manapun atau kegiatan politik termasuk pendanaan dan sebagainya

5. Kesukarelaan, organisasi bersifat sukarela tidak memaksa dan dipaksa terutama untuk angotanya

6. Kesatuan, di setiap negara hanya ada boleh satu organisasi yaitu Palang Merah saja atau Bulan Sabit Merah saja 
Ascosenda Ika Rizqi, Bunyamin Maftuh, Elly Malihah

Vol 5 No 1

ISSN : 2541-6995

E ISSN : 2580-5517

7. Kesemestaan, organisasi hadir di seluruh dunia, dinegara manapun pasti ada organisasi Palang Merah dan Bulan Sabit Merah

Selain di lindungi dengan Undang-Undang Nomor 1 tahun 2018 tentang Kepalangmerahan, para anggota Palang Merah juga di lindungi dengan Gerakan Internasional Palang Merah dan Bulan Sabit Merah yang sudah dijabarkan serta di lindungi oleh Saver Access dan Code Of Conduct dalam setiap melaksanakan tugas dilapangan baik dalam keadaan damai maupun dalam keadaan darurat yang mana merupakan kesepakatan dari tujuh badan kemanusiaan internasional, yaitu: ICRC, IFRC, Caritas Internasional, International Save the children, Lutheran World Federation, Oxfam dan World Council of churches. Adapun Code of Conduct atau pedoman etika dan perilaku Palang Merah yang diberikan kepada anggota Palang Merah adalah sebagai berikut:

1) Kewajiban kemanusiaan adalah prioritas utama

2) Bantuan diberikan tanpa membedakan ras, kepercayaan ataupun kebangsaan dari penerima

3) Bantuan tidak boleh diberikan untuk kepentingan politik dan agama

4) Tidak menjadi alat kebijakan pemerintah luar negeri

5) Menghormati kebiasaan dan adat istiadat

6) Membangun respon bencana sesuai dengan kemampuan setempat

7) Melibatkan penerima bantuan dalam proses manajemen bencana

8) Bantuan yang diberikan hendaknya untuk mengurangi kerentanan terhadap bencana dikemudian hari

9) Bertanggung jawab kepada pihak yang kita bantu dan yang memberi kita bantuan

10) Dalam kegiatan informasi, publikasi dan promosi harus memandang korban sebagai manusia yang bermartabat

Sedangkan Saver Access Palang Merah atau yang dikenal dengan tujuh pilar yang diberikan kepada anggota Palang Merah adalah sebagaimana berikut:

1) Penerimaan terhadap organisasi, artinya masyarakat harus mengenal dan memahami organisasi Palang Merah sehingga dalam melakukan pertolongan organisasi Palang Merah dan Bulan Sabit Merah bisa diterima oleh lapisan masyarakat.

2) Penerimaan terhadap individu dan tingkah laku pribadi, artinya selain bisa menerima organisasi dalam lapisan masyarakat, tentunya pribadi setiap anggota Palang Merah dan Bulan Sabit Merah juga harus di terima baik oleh lapisan masyarakat.

3) Identifikasi, artinya identitas Palang Merah dan Bulan Sabit Merah harus terus ada setiap saat dan masyarakat mengenal identitas Palang Merah dan Bulan Sabit Merah

4) Komunikasi Internal, artinya hubungan dengan sesama sukarelawan, pengurus dan staff harus terus berjalan

5) Komunikasi Eksternal, artinya hubungan dengan stakeholder dan para pimpinan diluar organisasi harus terus berjalan

6) Tindakan Perlindungan, Anggota PMI harus selalu mempersiapkan diri menghadapi segala risiko yang mungkin terjadi

7) Peraturan Keamanaan, artinya risiko terhadap keselamatan tugas di lapangan tentunya menjadi risiko yang dihadapi oleh masing-masing anggota PMI secara individu

Mendalami kasus yang terjadi beberapa waktu lalu, yang mana demonstrasi dan kerusuhan terjadi di Jakarta pada Desember 2019, demonstrasi yang berkaitan dengan penolakan hasil 
Ascosenda Ika Rizqi, Bunyamin Maftuh, Elly Malihah

Vol 5 No 1

ISSN : 2541-6995

E ISSN : 2580-5517

penghitungan suara pemilihan Presiden Indonesia 2019, tidak sedikit purnawirawan TNI-Polri yang mendukung salah satu pendukung calon presiden yang tergabung dalam Front Kedaulatan Bangsa menyatakan akan mengikuti demonstrasi ini di Komisi Pemilihan Umum, Mereka membantah turun ke jalan karena diperintah oleh salah satu calon pendukung, kepolisian Republik Indonesia (Polri) mencatat lebih dari 1.300 orang yang datang dari berbagai provinsi di Indonesia yang mengikuti demonstrasi tersebut. Dalam menghadapi peserta demonstrasi, Polri selalu menguatmakan negosiasi dalam pengamanan demonstrasi, namun Bentrokan massa dengan aparat dan kerusuhan terjadi di beberapa tempat di Jakarta tidak bisa terhindarkan lagi, hingga akhirnya terdapat kabar bahwa ambulans Palang Merah Indonesia Jakarta Timur di tuduh sebagai salah satu yang membantu mahasiswa dalam membawa "bantuan" guna menyerang apparat negara dalam hal ini adalah kepolisian, sehingga 4 unit ambulans PMI Jakarta Timur beserta sukarelawan PMI sempat di amankan oleh petugas kepolisian, hal tersebut tentunya mendapat kecaman dari juru bicara PMI Pusat yang saat itu bertindak tegas terkait tuduhan penyalahgunaan ambulans sebagai unit "bantuan" bagi pendemo pada malam demontrasi tersebut, karena ambulans sesungguhnya merupakan kendaraan yang disiapkan terutama dalam keadaan darurat, hal ini juga dijelaskan dalam Peraturan Pemerintah nomor 47 tahun 2018 pasal 5 ayat 3 tentang Pelayanan Kegawatdaruratan yang menjelaskan bahwa "Evakuasi medik sebagaimana dimaksud pada ayat (1) huruf b merupakan upaya memindahkan Pasien dari lokasi kejadian ke Fasilitas Pelayanan Kesehatan sesuai kebutuhan medis Pasien dengan menggunakan ambulans transportasi atau ambulans Gawat Darurat disertai dengan upaya menjaga resusitasi dan stabilisasi". Artinya bahwa ambulans benar-benar digunakan untuk mengangkut orang yang membutuhkan pertolongan terutama pada saat terjadinya demontrasi.

Organisasi Palang Merah Indonesia (PMI) merupakan organisasi yang bekerja sesuai dengan standar prinsip Palang Merah itu sendiri, dalam kaitan prinsip dasar berarti anggota PMI sudah melaksanakan protokol disetiap kegiatan termasuk demonstrasi, yaitu: prinsip kenetralan dan prinsip kemanusiaan, hal tersebut juga sudah sesuai dengan dengan prinsip dasar Gerakan Internasional Palang Merah dan Bulan Sabit Merah, yang pertama adalah kenetralan yang berarti organisasi Palang Merah tidak memihak siapapun dan yang kedua adalah tetap bekerja sesuai nilai kemanusiaan yang berarti juga organisasi Palang Merah bertindak sesuai keinginan memberi pertolongan tanpa membedakan korban yang terluka didalam pertempuran maupun memberikan bantuan dan pertolongan pada masa damai, mencegah dan mengatasi penderitaan sesama, di samping itu sesuai aturan code of conduct atau kode perilaku ada dua poin penting bagi anggota Palang Merah yang bekerja pada saat dilapangan, yang pertama yaitu bekerja berdasarkan kewajiban kemanusiaan merupakan prioritas yang artinya bahwa pengakuan atas korban bencana taupun konflik yaitu hak untuk memperoleh bantuan kemanusiaan dimanapun ia berada, komitmen untuk menyediakan bantuan kemanusiaan kepada korban bencana atau konflik dimanapun dan kapanpun diperlukan, akses terhadap lokasi bencana atau konflik dan terhadap korban tidak di halang-halangi serta dalam memberikan bantuan kemanusiaan tidak menjadi bagian dari suatu kegiatan politik atau partisan. Yang kedua merupakan bantuan diberikan tanpa pertimbangan ras, kepercayaan ataupun kebangsaan dari penerima yang artinya adalah bantuan kemanusiaan di perhitungkan berdasarkan kebutuhan semata, proporsional, mengakui peranan penting kaum wanita dan menjamin bahwa peranan tersebut harus didukung dan didaya gunakan serta terjaminnya akses terhadap sumber daya yang diperlukan serta akses yang seimbang terhadap korban bencana atau konflik. Di sisi yang lain anggota PMI juga bekerja sesuai dengan semua prinsip saver access atau mulai dari penerimaan terhadap organisasi hingga peraturan keamaan, 
Ascosenda Ika Rizqi, Bunyamin Maftuh, Elly Malihah

Vol 5 No 1

ISSN : 2541-6995

E ISSN : 2580-5517

dalam hal ini yang paling penting dari saver access adalah Tindakan perlindungan yang artinya anggota PMI harus siap dalam segala resiko.

Dalam kaitan konten Pancasila dan kewarganegaraan (PKn) inilah yang dinamakan perwujudan atau aktualisasi dari kebajikan atau keadaban kewarganegaraan (civic virtue), penampilan kecakapan kewarganegaraan (civic competence) dan perwujudan sikap kewarganegaraan (civic disposition). Palang Merah Indonesia (PMI) juga mengakualisasikan nilai-nilai Pancasila mulai dari sila pertama hingga sila kelima dan di implementasikan kedalam kehidupan sehari-hari yang tertuang dalam Gerakan Internasional Palang Merah dan Bulan Sabit Internasional, Saver Access dan Code of Conduct dalam setiap melaksanakan tugas terutama di lapangan. Dalam hal demokrasi, kaitan dengan dianggapnya penyalahgunaan ambulans sebagai "bantuan" bagi pendemo juga mencederai nilai-nilai demokrasi menurut Gunarsi (2014:90) itu sendiri, dalam hal ini pokok-pokok demokrasi yaitu pelaksanaan hak sosial serta perlindungan HAM, walaupun pada akhirnya telah diselesaikan melalui kelembagaan tetap saja organisasi menilai bahwa hal tersebut mencederai nilai demokrasi itu sendiri, tentunya juga berbanding terbalik dengan harapan demokrasi yaitu menjamin bagi warga negaranya dengan sejumlah HAM serta menjamin kebebasan yang lebih luas bagi warga negaranya.

\section{Kesimpulan}

Demonstrasi merupakan hal yang umum terjadi di setiap negara bahkan di negara demokrasi sekalipun seperti Indonesia sudah menjadi sesuatu yang sering di dengar dan di lihat. Demonstrasi terkait kebijakan pemerintah Indonesia yang terjadi beberapa waktu lalu memang sempat membuat kondisi wilayah terdampak demonstrasi sangat padat manusia dari beberapa wilayah dari tanah air. Palang Merah merupakan organisasi yang bergerak di bidang sosial kemasyarakatan, Palang Merah Indonesia (PMI) adalah organisasi kemanusiaan yang berstatus badan hukum, dalam melaksanakan tugasnya anggota PMI selalu berpedoman pada nilai-nilai Gerakan Internasional Palang Merah dan Bulan Sabit Merah serta Code of Conduct dan Saver Access sehingga dengan berpedoman kepada nilai-nilai tersebut anggota PMI bisa aman dalam melaksanakan tugas kemanusiaan disamping di lindungi oleh payung hukum melalui Peraturan Pemerintah dan Undang-Undang. 
Ascosenda Ika Rizqi, Bunyamin Maftuh, Elly Malihah

Vol 5 No 1

ISSN : 2541-6995

E ISSN : 2580-5517

\section{DAFTAR PUSTAKA}

Gunarsi, Sri dkk.2014. Pelaksanaan Nilai Demokrasi Di Kalangan Mahasiswa (Studi Kasus Pada Mahasiswa Program Studi PKn FKIP Ums Tahun Akademik 2014). UMS. Solo

Huda, Miftahul. 2013. Model-model Pembelajaran dan pengajaran. Pustaka Belajar: Yogyakarta

Nasih, Ahmad Mujin dan Lilik Nur Kholidah. 2009. Metode dan Teknik Pembelajaran Agama Islam. PT Refika Aditama: Bandung

Peraturan Pemerintah nomer 7 tahun 2019 tentang Kepalangmerahan

Sulesana. 2011. Demokasi dan Probematikanya di Indonesia. UIN Allaudin: Makassar

Tri, Dwi Sulisworo dkk. 2019. Bahan Ajar Demokrasi. Universitas Ahmad Dahlan:Yogyakarta

Undang-Undang nomer 1 tahun 2018 tentang kepalangmerahan 